\title{
'A riot in the heart': A Conversation with Author Benjamin Alire Sáenz
}

\author{
"Si te dan papel rayado, escribe de través; si atravesado, del derecho."1 \\ Juan Ramón Jiménez (1881-1958) (1990, p. 97)
}

Benjamin Alire Sáenz was born in 1954 in Old Picacho, New Mexico, and raised on a small farm near Mesilla, New Mexico. He is the fourth of seven children. He is a graduate of Las Cruces High School and earned a bachelor's degree from St. Thomas Seminary in Denver, Colorado. In addition, he studied theology at the Catholic University of Leuven in Leuven, Flanders, Belgium, from 1977 to 1981. He was an ordained Roman Catholic priest for a few years in El Paso, Texas, before leaving the order. In 1985, he studied English and creative writing at The University of Texas at El Paso (UTEP) where he earned a master's degree. He studied at the University of Iowa in pursuit of doctorate degree in American literature and later at Stanford University, where he was he was a Wallace E. Stegner fellow in poetry. Currently, he is a professor of creative writing at UTEP.

Sáenz's young adult novels are taught in many secondary schools and universities across the country. In addition to writing young adult novels, he is a children's book author, poet, and adult fiction writer. Sáenz is the recipient of numerous prestigious awards and honors such as the American Book Award, Pura Belpré Author Award, two Lambda Literary Awards, Lannan Poetry Fellowship, New York Public Library Book for the Teen Age, PEN/Faulkner Award for Fiction, Michael L. Printz Honor, Tomás Rivera Mexican American Children's Book Award, Southwest Book Award, Stonewall Award, and Young Adult Library

1 "If they give you ruled paper, write across it; if slanted, you write horizontally." [Aphorism 405. My translation.] 
Services Association Best Fiction for Young Adults. Currently, he is a professor of creative writing at UTEP, where he teaches in the bilingual master of fine arts program.

In the following conversation, Benjamin Alire Sáenz shares his love of writing for young adults and his connections to characters readers have grown to admire over the years. His young adult novel Aristotle and Dante Discover the Secrets of the Universe (2012) introduces readers to Ángel Aristotle Mendoza and Dante Quintana who possess a deep friendship and love between them. Like Sáenz, Aristotle and Dante are readers, writers, artists, and thinkers coming of age in a world dominated by rules and expectations. This universe is best summed up by Aristotle: "The problem with my life was that it was someone else's idea" (p. 8). Later, he adds, "I didn't want to live in my parents' world and I didn't have a world of my own"? (p. 81). The following conversation was conducted via email and face-to-face conversations from early Spring 2014 through early Spring 2015. The conversation begins with a brief interlude from a seminar session I observed.

\section{In the Desert Spring}

The Chihuahua Desert sun hovers over The University of Texas at El Paso campus as students make their way to classes during the spring semester. In the glaring heat, I make my way across campus to a creative writing seminar to see a professor-writer in action. Early and seated for class, the students are giddy and anxious with their books, pens, devices, and notebook paper-ready and in anticipation for a seminar with their professor, the writer Benjamin Sáenz. Anticipation's best. The students are spirited with curiosity about Professor Sáenz: the writer who brings to digital and print pages adolescent characters who become like family to them in the canon of young adult literatures. Admittedly, the students anticipate his presence as someone who knows the borderlands in 
person and through writing, connects with the people of the Chihuahua Desert as an inhabitant, and values the diversity of spoken languages and native cultures as a bilingual.

Although the students know Sáenz as a gifted and talented writer across genres and audiences, they possess a mixture of awe, confidence, and even uncertainty when approaching him. Like some of the characters he has introduced, the students are inquisitive; they want to know about his craft and how to further fuel their own reading and writing lives. Sáenz greets them with warmth. His smile and laughter are contagious. The seminar begins.

To sustain a writing life, Sáenz offers some wisdom: "The best of my teachers taught me to weigh my words carefully, to be disciplined enough to produce thoughtful work, to be sensible enough to accept that perfection is not possible, and to be intelligent enough to pay close attention to a material world which is the common site of our struggles." There is a humane presence and gentleness that Sáenz possesses before his students with complete trust in the possibilities through language.

Similarly, Sáenz’s poem "To the Desert" (1995) rings true to communicate a writing life deep in language and literary study. In a poetic incantation to the Chihuahua Desert, he writes: "You taught me how to live without the rain. / You are thirst and thirst is all I know. You are sand, wind, sun, and burning sky, / The hottest blue [... ] Break me, / I am bread. I will be the water for your thirst" (p. 96). Thus, our conversation begins about the desert, thirst, and belonging for a writing life.

\section{A Gift to Myself}

Rodrigo Joseph Rodriguez (RJR): At the beginning of the young adult (YA) novel Aristotle and Dante Discover the Secrets of the Universe (2012), Aristotle (Ari) explains, "One summer 
night I fell asleep, hoping the world would be different when I woke up. In the morning, when I opened my eyes, the world was the same" (p. 5). The novel's opening is significant as a recurring structure for narratives about looking inward as it has happened for literary characters such as Esperanza Cordero, Katniss Everdeen, Steve Harmon, Gregor Samsa, Piedad "Piddy" Sánchez, Melinda Sordino, and Rip Van Winkle. Tell us about the inspiration for writing this YA novel.

Benajmin Alire Sáenz (BAS): I was at a loss at what my next YA novel was going to be about. I'm such a serious writer. I always take on serious issues. I suffer over my writing projects. (I really think I should lighten up.) The art of writing is to make a novel feel as if it is about the people who are struggling with what the world has given them (usually not much). My protagonists-in all of my novels, be they for adults or young adults-are always situated in an exile, and they so much want to belong. Of course, I write about issues I deeply care about.

Novels aren't rants; they're not sermons. I'd already taken on racism, poverty, barrio life, and the Viet Nam war in Sammy and Juliana in Hollywood. Also, I'd taken on sons who didn't know their fathers in He Forgot to Say Goodbye. Lastly, I'd taken on abuse and addiction in Last Night I Sang to the Monster. So what now?

RJR: I am reminded of your sharing in a previous interview: "I love to write and I love to figure it out. It's like you're learning your craft all over again; each project is new and you learn something new. [...] I think I live between violence and tenderness. I think we all do. So I just try to incorporate that somehow into my art"(Peterson, 2013). Along the same lines, as much as Ari attempts to silence or walk away from Dante's sexual identity and attraction as a gay adolescent, Ari's father is most understanding and communicative as he 
supports his son's coming out-without stereotypical machismo or psychic violence-and walks his son through the many ways he has saved Dante's life. Is this all about coming out and to accepting ourselves first?

BAS: Because I had come out as a gay man at 54 and was getting used to that particular identity and how it felt in my body, in my mind and in my heart. I knew I wanted to tackle the subject of the difficulties of coming to terms with sexual identity. I didn't really know where to begin, because I'm no expert on the gay world-but because I'm an experienced writer, I knew all I had to was to write a believable character in a struggle to find who he was.

I said to myself: "That, I know how to do." It's no accident that the novel begins with Ari lying in bed. And not really wanting to wake up. That was me. I started writing the first few scenes and it felt right. But then fear and doubt started to set in. I was more than a little afraid of writing the novel because I didn't feel comfortable coming out in the literary world in such a public manner. I almost told myself to "forget it."

RJR: In a recent book, Sadowski (2013) argues, "To grow up lesbian, gay, bisexual, transgender, or queer (LGBTQ) in the United States is to be aware of a profound silence in our relationships, our society, and in many cases even ourselves" (p. 1). Does this resonate with the writing of the YA novel about Aristotle and Dante?

BAS: I decided that I'd already spent too much time living in fear, too much time in running away from myself. In short, I decided to be brave and write the novel. It was a painful novel to write, but then again all my novels are painful to write. Really, I had no idea that what I was writing would touch so many people. 
In the end, I think I wrote this book as a gift to myself. To heal myself. The inspiration for Ari and Dante, in the end, was my own hurt.

RJR: Ari is quick to describe his dilemma in three statements of adolescent angst and awareness:

I was fifteen.

I was bored.

I was miserable. (p. 5)

Ari is the youngest in a family of four children, while Dante is an only child. For Ari, his siblings are complicated: his sisters are much older than he is, and his older brother Bernardo is incarcerated. He is a loner when he meets Dante at the swimming pool. The novel opens with essential questions that set the stage for an adolescent life of yearning, searching, and struggle:

Why do we smile? Why do we laugh? Why do we feel alone? Why are we sad and confused? Why do we read poetry? Why do we cry when we see a painting? Why is there a riot in the heart when we love? Why do we feel shame? What is that thing in the pit of your stomach called desire? (p. 4)

How did you come to these opening questions for a YA audience that really grab us by the throat the beginning of the novel?

BAS: I am very fond of epigraphs. I use them all the time. Usually, I find quotes from poems or novels I've read that I feel are appropriate and that help me fully understand what I'm tackling. But this time I wrote the epigraph myself. Epigraphs are compasses that point the reader towards the meaning of the novel. Those questions came out easily. I think I've kept 
those questions locked inside me all my life. They are very basic questions not only for young adults but for adults, as well. We try to understand what cannot be fully understood.

Love is, in fact, a riot in the heart. I don't know why. I don't. I don't know where desire comes from. I do know that if we didn't have desire, then our lives would be impoverished. I do know that if we don't rid ourselves of shame, then we will never be happy. Yes, these are very basic questions.

\section{Aristotle and Dante}

RJR: Ari and Dante's friendship takes the form of revealing dialogue about boyhood to manhood and evolves through adolescence during 1987 and 1988 that includes a car accident injury faced by Ari, a violent gay assault and bashing survived by Dante, Dante's move from El Paso to Chicago for nine months, the death of Ari's beloved Aunt Ophelia, Ari finding out about his brother Bernardo's past and present, and Ari coming out to himself.

You're a lover of world languages and given names. Their names can reveal the connection from the historical, literary, and theoretical to the mundane existence that can be adolescence as they experience it. Named after his grandfather, Ari dislikes his first name, Ángel, and middle name, Aristotle. He attempts to come to terms with these names, but settles for other possibilities and a shortened name. Ari explains:

Everyone expected something from me. Something I just couldn't give.

So I renamed myself Ari.

If I switched the letter, my name was Air.

It thought I might be a great thing to be the air. 
I could be something and nothing at the same time. I could be necessary and also invisible. Everyone would need me and no one would be able to see me. (p. 84)

Dante shares his father's advice with Ari: “My dad says it's alright if people make fun of you. You know what he said to me? 'Dante, you're an intellectual. That's who you are. Don't be ashamed of that"' (p. 35).

Tell us about your choosing the male characters' names as Ángel Aristotle Mendoza and Dante Quintana.

BAS: Ángel is an important name. Even though we know Ari as Ari, we know his real name. And he is a wounded angel. He doesn't recognize his own decency, and in his own mind he has fallen from grace. He is unaware of his own courage. But to have named him Ángel and left it at that would have been too much.

And I love what those two names conjure. Aristotle: the philosopher who staked out a reputation by theorizing on what it means to create art and to be human. Dante: the artist. The names are unusual, but not that unusual. By choosing those names I elevated both of them into the realm of the gifted. Dante embraces his gifts and uses them. Aristotle doesn't even know he has any gifts.

RJR: The need to name adolescence and masculinity involves questioning one's own behavior and sense of belonging. In the novel, when two adolescent lifeguards attempt to woo two girls as "budding Walt Whitmans" with offensive verbal harassments such as "A girl is like a tree covered with leaves. You just want to climb up and tear all those leaves off," Ari realizes that he abhors their presence and questions their performance and even their abilities as lifeguards. Ari observes: 
I just didn't belong. I think it embarrassed the hell out of me that I was a guy. And it really depressed me that there was the distinct possibility that I was going to grow up like one of those assholes. A girl is like a tree? Yeah, and a guy is about as smart as a piece of dead wood infested with termites. My mom would have said they were just going through a phase. Pretty soon they would get their brains back. Sure they would. (p. 16)

Furthermore, Ari fathoms about Dante: “I didn’t understand how you could live in a mean world and not have any of that meanness rub off on you. How could a guy live without some meanness? Dante became one more mystery in a universe full of mysteries" (p. 19).

Ari is not convinced that the masculine adolescent behaviors he observes are part of him and his identity for membership as he reflects, "Boys. I watched them. Studied them. [. . .] Being around guys made me feel stupid and inadequate. It was like they were part of this club and I wasn't a member" (p. 22). In contrast, in the presence of females, both Ari and Dante evolve into their own person, yet interconnected to each. Tell us about the names you've chosen for them.

BAS: As readers, we understand perfectly that Ari doesn't have a clue as to his own beauty. We see him through his mother's eyes. We see him through his doctor's eyes when he tells Ari: "I'm on to you." In the end, the reader has a feeling that they will become their names as they journey towards the country of manhood.

RJR: In the past, you've explained that when young adults are fifteen years old, they are a "kind of a philosopher and thinker" (Martin, 2013). Moreover, Jiménez's aphorism seems apt about the Ari and Dante's universe and realities that reflect the ruled and unruled in 
their lives and on paper. For instance, Ari and Dante view their identities and Mexican origin with a diverse, perhaps even competing, lens as adolescents.

What were some of your interests in naming these rules as well as their maleness, ethnic identities, social class, nationalism, and sexuality as youth living and getting schooled in the Ciudad Juárez and Paso del Norte border region?

BAS: Too many people, who should know better, have a very particular view of what it means to be Mexican American. We often contribute to this stereotypical view ourselves when we begin (perhaps unconsciously) performing our own ethnicity. Tamales, tortillas, tacos, mariachis: the works. (I love all of those things, by the way.) That said, I absolutely refuse to do that. I don't have to prove I'm Mexican American; I am Mexican American.

There is as much diversity in our masculine identities as there is in the dominant culture at large. We are not all brown: Ari is dark; Dante is fair-skinned. All of us do not even have Spanish-language first names and surnames. We come from all social classes and we all have different relationships to the country we live in-and we have different relationships to México. Ari and Dante (like me) live in a cultural ecotone, an in-between liminal space between the competing cultures of the United States and México.

RJR: In the preparation of English language arts and literacy teachers, Burke (2013) asks: "Can we continue to teach only Hamlet, Huck, Holden, and Harry (Potter) when more and more of our students are named Jesús, Hishem, or Xiaohui Han?" (p. 30). Tell us about the significance in the shaping of identities of both ourselves as teachers and students and the characters we are reading across various self-identifications and public identifiers such as age, countries, ethnicity, gender, neighborhoods, race, sexual preference, and social class, among others. 
BAS: All Ari and Dante are trying to do is to situate themselves in the borderlands of national identities. And yes, of course, there is the culture of machismo that permeates both Mexican and U.S. cultures. The macho characteristics may operate a little bit differently in each country, but it is a great hypocrisy to think that Americans themselves don't suffer under machismo. In fact, the culture of machismo permeates into gay culture as well-and every gay man knows it. The borderlands lives in constant struggle negotiating between all these spaces. Sometimes, I feel that those of us who reside in the El Paso, Texas/Ciudad Juárez, Chihuahua, México metroplex are hated by all sides.

This is the situation: Mexicans hate us for not being Mexican enough; Americans hate us for not being American enough. We don't know English; we don't know Spanish. We're disloyal to the United States; we've betrayed Mexico. It goes on and on. Although I am proud of my ethnic culture, history, and identity, I am every bit as American as the guy watching Fox News in Indiana.

\section{Writing the YA Literature and the Borderlands}

RJR: The border of the Ciudad Juárez, Chihuahua, México / El Paso, Texas, USA region and landscape of the Chihuahua Desert appear in your YA narratives. Like your characters, you grew up along the U.S.-México borderlands and in the Chihuahua Desert, which offers a sense of place through the landscape as well as the bilingualism and bicultural experiences of Mexican-origin people.

Regarding language and the world of young adults, you make many connections with your readers of ages and backgrounds and also with your own creative writing students at UTEP. You've explained in the past: 
I'm really grateful to my students because they keep language alive and fresh for me and they remind me that no one needs permission to speak the English language. When I listen to my students, I learn new words and new ways of using language, and they remind me that language doesn't belong to me-it belongs to all of us. (Garibay, 2013)

In addition, you've stated, "The borderland-the frontera-gave me words, gave me language, a point of view" (Ramirez, 2013). Tell us more about the people and landscape so prominent in your work and across all genres, which you've mastered so well.

BAS: I love the El Paso/Ciudad Juárez cultural landscape just as I love the literal landscape of the Chihuahuan Desert. I am a writer of place (which doesn't make me very unusual). I believe that all of us belong to a community-or better put we belong to many communities. It is ungracious and morally indecent to cut ourselves off and disavow the village that raised us. My village is here, on the border.

I don't want to live in a place where it is easy to live, where everyone is progressive, where poverty is shoved out of sight as if it wasn't really there. I don't want to live in a suburb where the strip mall is king, cut off from the diversity of classes and cultures that make us more open and compassionate and challenge us to think about who we really are as a people, as a nation. I don't want to live alongside people who are just like me.

I love this place, because Ciudad Juárez is visible everywhere, along with its poverty and its generous, humble people. People who think that people are poor because they're lazy are either just plain mean, or they're willfully ignorant. The people of Juárez are some of the most hard-working people in North America. Humility is not a word we value in America-and we certainly don't value it in our political discourse. 
I love this place, because it constantly reminds me that it is a blessing to live in uncertainty. I love this place, because it reminds me that the U.S. and México cannot divorce each other. I love this place, because it has given me a humane politics and has reminded me that having a U.S. passport doesn't necessarily make me a virtuous person.

I cannot imagine myself speaking only one language. I continually have to question myself and question the economic and political motivations of the country I live in and the economic and political motivations of the country across the Río Bravo. Living here has made me a critical thinker and, without that gift, I would be a very poor writer.

RJR: Teacher and researcher David E. Kirkland (2014) writes, "Stereotypes rely upon silence" (p. 9). In your novel, stereotypes about adolescents, Mexican-origin people, and young gay adolescents are challenged and come undone with a more humane lens for young people to experience. What are some of your thoughts on writing new ways of seeing the world and writing the silences of adolescence?

BAS: I do believe the paradigms we use to view the "Other" must be torn down. We are, after all, just people. Being a gay man doesn't make me a pervert. I'm not all that different from any straight man. I don't believe straight men are more virtuous than gay men. I don't believe that straight women are more virtuous than lesbians. I want what everybody wants - the freedom to pursue happiness with my heart, my mind, and my body.

RJR: In the critical essay "Sexuality at Risk and Resistance in Young Adult Literature," Lewis and Durand (2014) argue, "From the time Hester [Prynne] was pinned with a scarlet letter, sexuality has been viewed by our society as, at best, rife with personal and social consequences; at worst, as sinful activity. These particular perspectives have significant 
effects on the lives of youth due to the adult gaze under which they live" (p. 38). How are these negotiated in the writing of your characters?

BAS: I am not the most masculine of men when we use Clint Eastwood as the standard. But I am a man. I refuse to be emasculated just because I'm gay. I'm uncomfortable with the word joto just as I'm uncomfortable with the word "queer" or "fag." [Joto can be a pejorative term in Spanish for gay, although being reclaimed in a positive connotation like "queer."] Maybe I'm just old school, but those words wear away at my dignity; I won't play into the hands of homophobes who expect a certain kind of behavior from us.

Just as I refuse to perform my own ethnicity, I refuse to perform my own gayness. I wrote Ari and Dante not as gay boys—but as boys. Confused, tender, beautiful, flawed boys who are deeply loved by their parents.

RJR: Human sexuality and sexual identity in young adult literature can be present, ignored, or absent. Abate and Kidd (2011) claim, "Even as boys and especially girls are sexualized in Western mainstream culture-in popular fashion and advertising, for instance-they are still often presumed innocent of sexuality" (p. 13). How would you say Ari's and Dante's identities and love for each other come together?

BAS: In the end, Ari and Dante find that they are in love with each other. That makes them gay, but that doesn't take away from the fact that they are boys. Teen love is confusing and tender and lovely and lonely—and it's not just something that happens between a boy and a girl. But let me get back to this thing we call gay. What, in the end, is a "gay identity," and what is "gay culture?" I sure as hell don't know.

\footnotetext{
${ }^{2}$ The Spanish-language term joto can be used pejoratively for a gay male, although recent efforts are to revise and reclaim the term in a positive connotation such as "queer."
} 
RJR: This reminds me of what Matos (2012) notes about your novel, "[W]e witness an instance in which the father figure (who is typically represented as chauvinistic, patriarchal, and homophobic in other gay novels with Latino characters) disrupts heteronormative stereotypes by nurturing, rather than suppressing, his son's homosexuality."

BAS: Well, we also have this stereotype that Latinos reject their gay sons and lesbian daughters. That happens not to be true. In early 2014 , there was a family business painting my sister's house. A father, a son and his wife, a daughter and a cousin. The daughter is partnered with another woman. There are difficulties for the father, I'm sure, but certainly no rejection. It was very clear that there was a lot of affection in this hard-working, Mexican-American family. They had no formal education to speak of. You don't have to have an enlightened Stanford education to embrace your own children. Speaking of parents, I wanted to break the stereotype of the working Mexican.

Yes, there are many working poor Mexican Americans in this country. But there are millions of us who are educated and have integrated into American society. In creating Ari and Dante's parents, I wanted to represent a more realistic view of who we are (and not who outsiders think we are). Many of us (I include myself in this category) are educated, articulate, working professionals. We don't all pick onions for a living.

RJR: Janet Alsup (2010) argues, "Readers can change through vicarious experience; they can grow, develop, ask new questions, think new thoughts, and even feel new emotions. All from reading a book" (p. 5). Tell me your perspective about the writer and reader. 
BAS: I write for myself. Truly. That may sound incredibly egocentric, but it happens to be true. I write because I need to write. I write to save my own life and to articulate the hurts and wounds and troubles and hopes that reside in the deepest corners of my heart.

Yes, I write to touch other people, to reach other people. I do believe that books can stir our emotions and make us a more compassionate people. Not only has writing changed the shape of my heart, reading has changed the shape of my heart. I'm constantly (and happily) surprised at how my readers have reached out to me, telling me how my books have touched or even changed their lives. It's not my books that are doing the changing.

If a reader is open to the message of the book and gives himself or herself over to the book, then something happens. Something rare and beautiful. Not only does the writer have to be brave and vulnerable-the reader has to be brave and vulnerable, too.

I believe that novels, whether they are for adults or young adults, have the ability to tame our uncivil public discourse. We are living through times where hate speech has become all too common-especially in our political discourse. We live in divisive time. Through a novel, perhaps we can regain some of our humanity and be reminded that we really do belong to one another.

\section{Rules and Bravery}

RJR: The world filled with rules, expectations, and demands appears often in your writing for adolescents and how adolescents face their circumstances to name themselves. In Aristotle and Dante Discover the Secrets of the Universe, the novel's dedication is telling: "To all the boys who've had to learn to play by different rules."

The rules and expectations become unsettling and burdensome for Ari that may come from his given, inherited name. Among the rules in Ari's world are as follows: 
1. Better to be bored by yourself than to be bored with someone else. (p. 17)

2. No secrets. (p. 49)

3. No crying. (p. 116)

4. We won't talk about the accident. Not ever. (p. 128)

5. I don't kiss boys. (p. 428)

However, these rules are broken as Ari and Dante's struggles are revealed. They must come to terms with their love for one another. Spoken and written language, which can become the vehicle for dialogue, is insufficient for Ari as he comes of age and observes, “Words were not things you could control. Not always. I didn't know what was happening to me. Everything was chaos and I was scared" (p. 97).

Also, in your short story titled "The Rulemaker," rules and expectations drive the inner and external conflicts of the characters. Tell us about the dedication and role of rules in the lives of Ari and Dante.

BAS: When we are boys and girls, our lives really are somebody else's idea. We need rules and boundaries in order to survive; otherwise, it's all chaos. The problem is that these rules are the constructions of the parents who raised us and are infused with the values of the surrounding culture(s). Adolescents internalize all of this-and this is not entirely bad.

There are flaws in the system. Racist parents teach their children to be racist. U.S. citizens are taught to believe that they are de facto superior by virtue of the place where they are born. None of us is responsible for where we were born. Almost every religion teaches their followers to believe they are the chosen people.

What happens when you find yourself outside the norm of the values of your parents or the culture you were raised in? What do you do? Do we simply disappear and 
spend our lives in misery? I am happy that we are finally having a very public debate on issues that concern the LGBT community.

However, we will always be in the minority. Unlike Latinos, we do not reproduce. The United States may well become a country where ethnic minorities are the majoritybut we will never be a country where gays and lesbians are in the majority. We will have to rely on the civility and compassion of heterosexual majority for our survival. The entire LGBT community, whether most people know it or not, has had to learn to be very brave. And so, my dedication.

RJR: DeWitt (2012) believes, "When we open a good book and read about a character that we identify with, it's like the weight of the world goes away and everything around us is going to be all right" (p. 43). To take DeWitt's perspective further, tell us how you remain connected to adolescent life as a writer, educator, and reader.

BAS: I am in the presence of young people every day of my life. Believe me, a lot of my students aren't all that far away from the high school experience, and they are still coming to terms with who they are. I observe their struggles and have nothing but compassion for the stage in life they are going through.

We may romanticize about being young, but we do so at our own peril. Young people's struggles are very real, but thank God they have the energy and the stamina to face their days. I visit schools all the time and am grateful for those visits. Indeed, there is still a lot of boy living inside me. Maybe that's why I always wear Chuck Taylors.

RJR: In a recent book, Antero Garcia (2013) concedes, “[A] book caters to its marketed audience long before someone breaks the spine and begins digesting the prose between its covers. Instead, the way books are designed plays and important role in how consumers 
know if a book is for and about them. This is particularly clear when it comes to conveying race within books" (p. 38). Which books do you recommend today to an adolescent interested in becoming a YA author in the future?

BAS: There are so many great books out there. So many great authors! What's important is that future YA authors become well-read. Reading isn't really a systematic thing. For every book we read, ten go unread. Still, authors have a duty to be well-read. If an author isn't generous enough to read other writers' works, then why should he or she expect any audience at all?

I strongly believe that YA authors should read outside the genre. In other words, read adult fiction, too. Reading Gabriel García Márquez and the poetry of Pablo Neruda can broaden any writer's perspective. Read Leo Tolstoy, Charles Dickens, Flannery O'Conner, Ernest Hemingway, Toni Morrison, Ralph Ellison, Richard Wright.

Read poetry. Find writers you love and analyze why you love them. Be eclectic in your reading.

Broaden your horizons. All of this will make you a better human being and a better writer.

RJR: Thank you for sharing your words and thoughts with us, Ben. We are grateful for your contribution to our letters.

BAS: Con gusto, Joseph. Thank you. 


\section{References}

Abate, M. A., \& Kidd, K. B. (Eds.) (2011). Over the rainbow: Queer children's and young adult literature. Ann Arbor, MI: University of Michigan Press.

Alsup, J. (2010). Young adult literature and adolescent identity across cultures and classrooms: Contexts for the literary lives of teens. New York: Routledge, 2010.

Burke, J. (2013). The English teacher's companion: A completely new guide to classroom, curriculum, and the profession (4th ed.). Portsmouth, NH: Heinemann.

DeWitt, P. (2012). Dignity for all: Safeguarding LGBT students. Thousand Oaks, CA: Corwin Press.

Garcia, A. (2013). Critical foundations in young adult literature: Challenging genres. Rotterdam, The Netherlands: Sense Publishers.

Garibay, L. Y. (2013, Spring/Summer). UTEP professor wins 2013 PEN/Faulkner Prize for Fiction. UTEP Magazine 5(2), 36-38. Retrieved from http://utepmagazine.utep.edu/downloads/utep_magazine-spring-summer2013.pdf

Jiménez, J. R. (1990). Ideolojía (1897-1957): Metamórfosis, IV. A. Sánchez Romeralo (Ed.). Barcelona: Anthropos.

Lewis, M. A., \& Durand, E. S. (2014). Sexuality as risk and resistance in young adult literature. In C. A. Hill (Ed.), The critical merits of young adult literature: Coming of age (pp. 38-54). New York: Routledge.

Martin, M. (Narrator). (2013, February 20). Discovering sexuality through teen lit [Radio broadcast episode]. In D. I. Ardalan (Producer), Tell Me More. Washington, DC: National Public Radio. Retrieved from 
http://www.npr.org/2013/02/20/172495550/discovering-sexuality-throughteen-lit

Matos, A. D. (2013, October 20). On YA fiction with gay Latino characters: Benjamin Alire Sáenz's Aristotle and Dante discover the secrets of the universe. Retrieved from http://angelmatos.net/2013/10/20/aristotle-and-dante/

Peterson, K. M. (2013, January 31). Between violence and tenderness: Aristotle and Dante author Sáenz talks to SLJ. School Library Journal. Retrieved from http://www.slj.com/2013/01/authors- illustrators/interviews/betweenviolence-and-tenderness-aristotle-and-dante-author-saenz-talks-to-slj/\#_

Ramirez, C. (2013, March 19). El Paso author Benjamin Alire Sáenz wins PEN/Faulkner Award for Fiction. El Paso Times. Retrieved from http://www.elpasotimes.com/ci_22823132/el-paso-author-benjamin-alire-saenzhonored-his-border-stories

Sadowski, M. (2013). In a queer voice: Journeys of resilience from adolescence to adulthood. Philadelphia: Temple University Press.

Sáenz, B. A. (2012). Aristotle and Dante discover the secrets of the universe. New York: Simon \& Schuster BFYR.

Saenz, B. A. (1995). Dark and perfect angels: A collection of poems. El Paso: Cinco Puntos Press. 


\section{Recommended Works by Benjamin Alire Sáenz}

\section{Young Adult Novels for Reading by Teachers and for Adolescent Study}

Sáenz, B. A. (2010). He forgot to say goodbye. El Paso, TX: Cinco Puntos Press.

Sáenz, B. A. (2011). Sammy and Juliana in Hollywood. El Paso, TX: Cinco Puntos Press.

Sáenz, B. A. (2012). Last night I sang to the monster. El Paso, TX: Cinco Puntos Press.

Sáenz, B. A. (2012). Aristotle and Dante discover the secrets of the universe. New York: Simon \& Schuster BFYR.

\section{Bilingual Children's Books to Use as Mentor YA Texts to Teach the Craft of Writing}

Sáenz, B. A. (1998). A gift from Papá Diego: Un regalo de papá Diego. El Paso, TX: Cinco Puntos Press.

Sáenz, B. A. (2001). Grandma Fina and her wonderful umbrellas: La Abuelita Fina y sus sombrillas maravillosas. El Paso, TX: Cinco Puntos Press.

Sáenz, B. A. (2008). A perfect season for dreaming: Un tiempo perfecto para soñar. El Paso, TX: Cinco Puntos Press.

Sáenz, B. A. (2012). The dog who loved tortillas: La perrita que le encantaban las tortillas. El Paso, TX: Cinco Puntos Press. 